\title{
KARST TERRAINES IN IRAN - EXAMPLES FROM LORESTAN
}

\author{
KRAS V IRANU - \\ PRIMERI IZ LORESTANA
}

MOHAMMAD REZA AHMADIPOUR ${ }^{1}$

${ }^{1}$ Head of Geology Dept., Lorestan University, Lorestan, ISLAMIC REPUBLIC OF IRAN

Prejeto / received: 25. 8. 1999 


\section{Mohammad Reza Ahmadipour: Kras v Iranu - primeri iz Lorestana}

Kraški svet predstavlja $13 \%$ ozemlja Irana. Karbonatne kamnine so eocenske, oligo-miocenske, miocenske, jurske in kredne starosti. Večina jih je razvitih v bazenih Mazindarana in Zagrosa. Zaradi prevladujočih tektonskih aktivnosti so kamnine zagroške cone bolj zakrasele. $56 \%$ vseh izvirov je prav v tej coni. Lorestansko in zagroško cono sestavljajo vzporedne antiklinale v katerih so, zaradi tektonskih premikov, kamnine nagubane in razpokane. Nagubanost in prepokanost je osnova vodonosnikov. V Karbonatnih kamninah Lorestana so razvite vse kraške oblike, kot škraplje, vrtače in jame. Njabolje razvite kraške oblike je videti v skupini Bangeston. Večina izvirov je vzdolž tektonskih linij ali na križišču teh linij. Kemične analize kažejo, da so vode bikarbonatnega tipa. Prestolnica Lorestana, Khorramabad, se oskrbuje z vodo iz kraških izvirov. Prispevek podrobneje obravnava kraško hidrologijo dveh pomembnejših regij v Lorestanu.

Ključne besede: geologija, kraška hidrologija, oskrba z vodo, Lorestan, Iran.

\section{Abstract}

UDC: $551.44(55)$

\section{Mohammad Reza Ahmadipour: Karst terraines in Iran - Examples from Lorestan}

In Iran karst terrain covers about 13\% of the total area. The carbonate rocks belong to the Eocene, OligoceneMiocene, Miocene, Jurassic and Cretaceous. Most of the carbonate rocks are developed in the basins of Mazindaran and Zagros. The carbonate rocks in the Zone of Zagros, due to the prevailing tectonic activities, have undergone more processes of karstification. About $56 \%$ of all the springs originated from this zone. In Lorestan the Zagros zone consists of a series of parallel anticlines in which, due to the tectonic movements, the rocks have undergone folding and fracturing. The folding and fracturing have created rich ground water reservoirs. The carbonate rocks of Lorestan show all types of karst features such as karren, dolines and caves. The most developed karstic features are seen in the Bangeston group. Most of the springs are discharged either along the lineaments or at the intersection of the lineaments. The chemical analyses of the samples show that they are of bicarbonate type. The drinking water of the city of Khorramabad (capital of Lorestan) is supplied from the karstic springs. In this paper, the karst hydrology of two important regions of Lorestan are considered.

Key words: geology, karst hydrology, water supply, Lorestan, Iran. 


\section{INTRODUCTION}

In Iran karst terrain covers about 13\% of the total area of the country. Due to the situation of Iran in the middle belt of Alps-Himalaya and between the two platforms of Eurasia in the north and Gondwana (Africa-Arabia) in the south, secondary fractures and tectonic lines have favoured a suitable condition for the development of karst. The carbonate rocks belong to the Eocene, OligoceneMiocene, Miocene, Jurassic and Cretaceous. Fig. 1 shows the distribution of the carbonate formations in Iran (Price \& Cosgrove 1990; Raeisi \& Kowsar 1997).

Most of the carbonate rocks are developed in the basins of Mazindaran (north) and Zagros (northwest to southeast). The carbonate rocks of the Zagros zone, due to tectonic activities (Colman \& Saad 1978) and karstification, show more development of karst. About 56\% of the springs and most of the big rivers of Iran originate in this zone. The discharge of some of the karstic springs

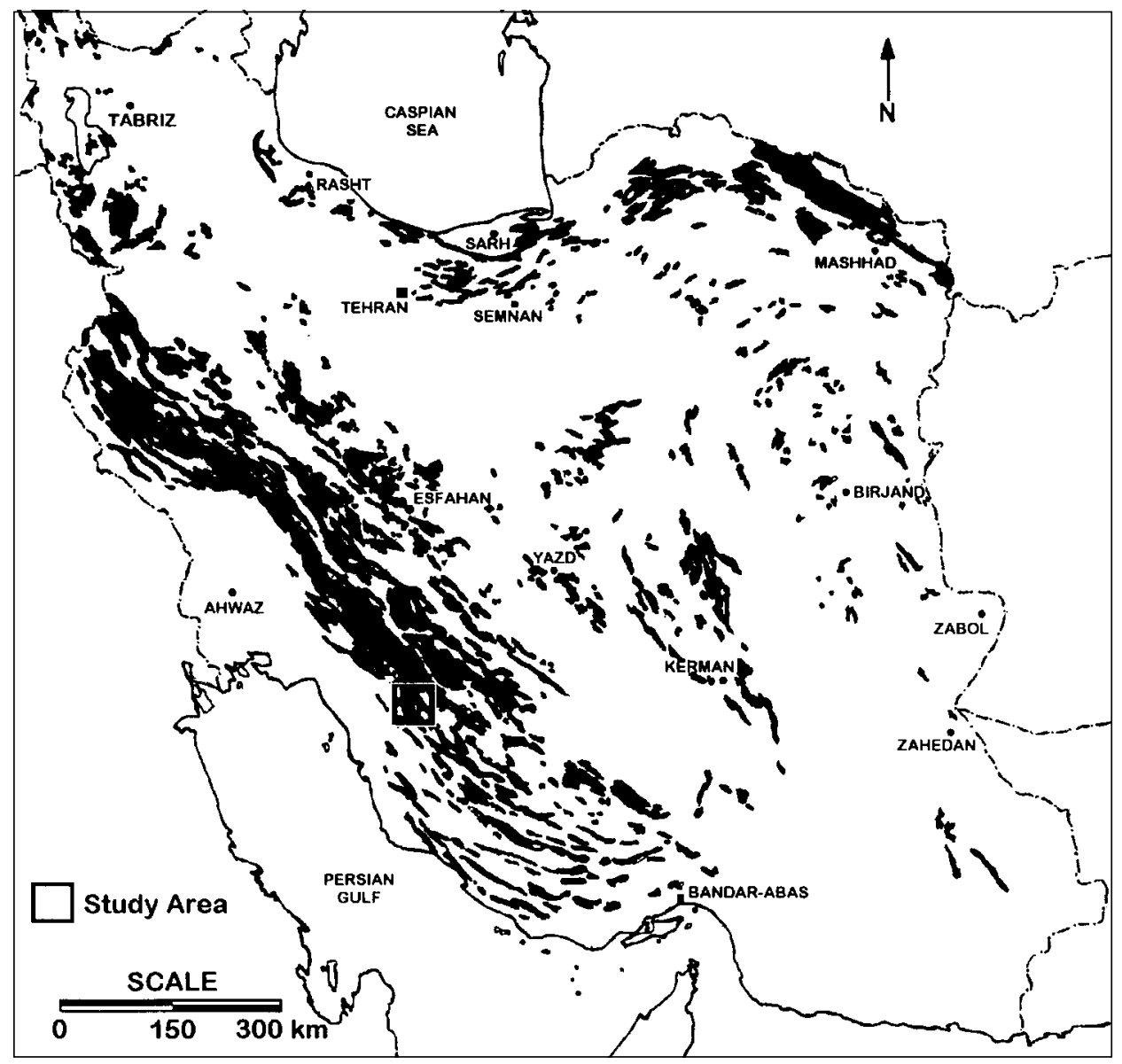

Fig. 1: Distribution of karst formations in Iran. 
reaches 3 cubic meters per second. The Zagros covers about 15500 square kilometres from the Taurus Mountains in the southwest of Turkey to the south of Iran. The general trend is NW to SE. On the bases of the reports from the Ministry of Energy more than 13000 meters of boreholes have been done in order to extract the water needed for agricultural, industrial and drinking purposes (Ramsay \& Huber 1987; Rowland 1986). The two important basins of Dez and Karkah get their waters from carbonate rocks of Lorestan. The annual discharge of these two basins reaches 12 milliard cubic meters.

The carbonate rocks of Lorestan show all types of karst features such as karren, dolines and caves. Most of the springs are discharged either along the tectonic lines or at the intersection of the tectonic lines. The chemical analyses of the samples show that they are of bicarbonate type. In the southern part of Lorestan there is wide extension of the carbonate rocks, but the karstic features are best developed in the Bangeston group. The most developed karstic features such as karren, dolines, and caves are seen just in the Bangeston group. For this reason, in order to supply the drinking water for the city of Pole-Doghtar with a population of about 20000 people, three wells were drilled at the foot of the Sultan anticline. At present, the water of these wells is being pumped with a discharge of about 120 liters per second. The drinking water of the city of Khorramabad (capital of Lorestan) is supplied from karstic springs too.

The solutional features are the main avenue for transmitting and storing water potentials in the area, but due to the high transmissibility, they can be readily affected by the pollutants. The high concentration of nitrates in some of the karstic waters of Lorestan province is an indication of pollution.

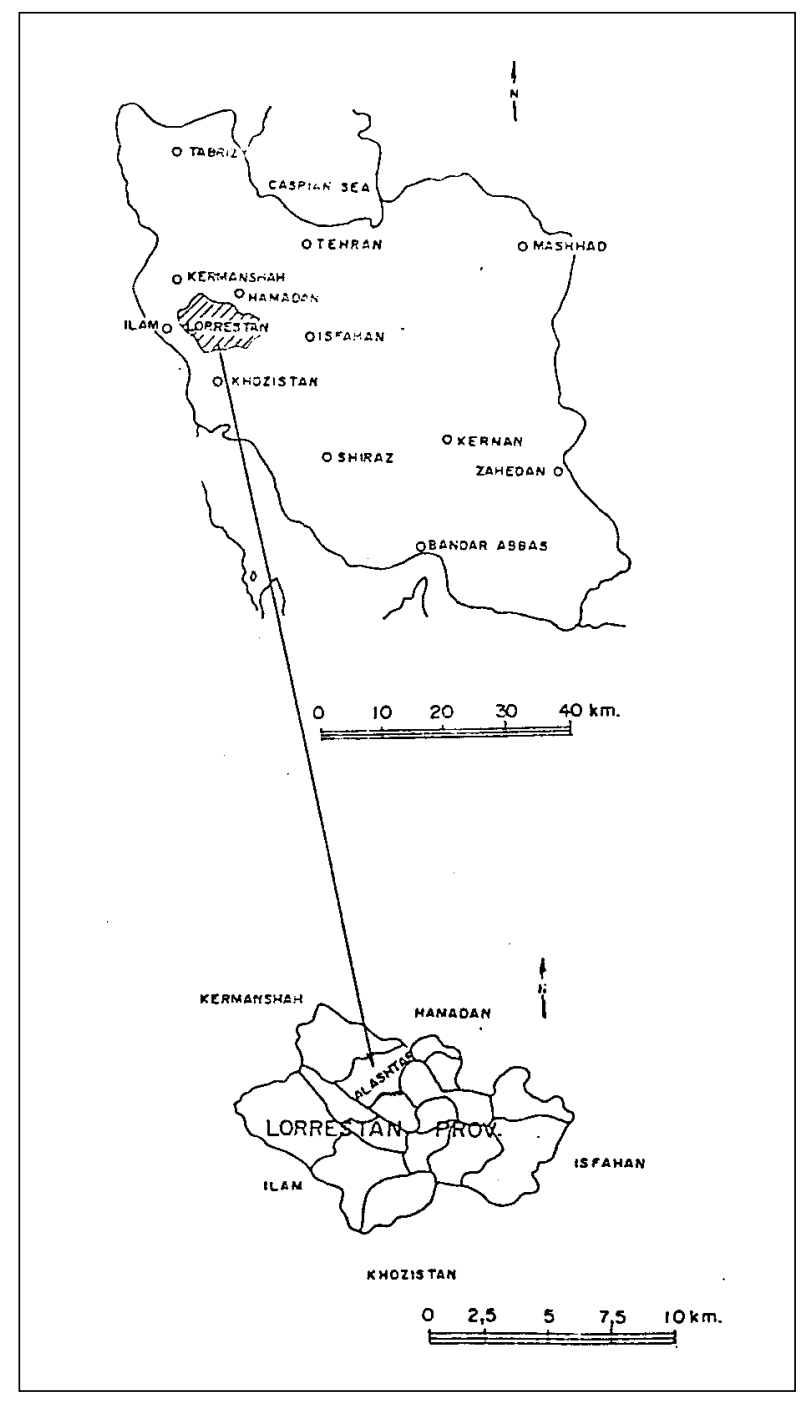

Fig. 2: Situation of Lorestan Province. 


\section{KARST TERRAIN IN LORESTAN}

Lorestan province is situated in the western part of Iran along the Zagros zone. Fig. 2 shows the position of Lorestan province. The area of this province is 28560 square kilometres. The mean annual precipitation is $550 \mathrm{~mm}$.

\section{Carbonate Rocks}

The carbonate rocks constitute about $25 \%$ of the total area of the province.

The age of the rocks is Eocene, Oligocene-Miocene, Jurassic and Cretaceous. Due to the tectonic movements and the action of water, solutional features have created good water channels and reservoirs. The two important basins named as Dez and Karkhah receive their waters from the carbonate rocks of Lorestan. The annual discharge of these two basins from the territory of Lorestan is 12 milliard cubic meters which is equal to $1 / 8$ of the total surface waters of the country. In this paper two important karst terrains of Lorestan, named Alashtar and Khorramabad, are considered (Ahmadipour 1989).

\section{Karst in Alashtar}

Alashtar is situated in the north west of the city of Khorramabad. The most important carbonate rocks of this area belong to Eocene and Jurassic-Cretaceous. Due to the tectonic activities, tectonic lines have developed and along which a few karstic springs have emerged. The Jurassic-Cretaceous rocks cover most of the surroundings of the area and have an important role in the recharge of the plain. Fig. 4 shows the influence of the Jurassic-Cretaceous rocks in the recharge of the plain. Solutional features are mostly developed along the bedding planes (Fig. 3).

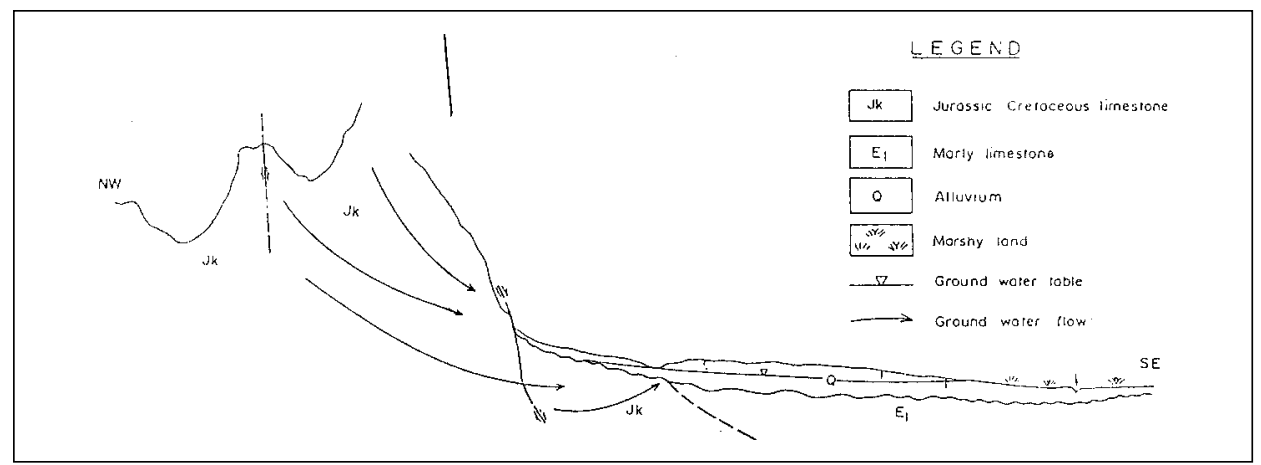

Fig. 4: Influence of the JK rocks in the recharge of the plain.

\section{Springs}

There are six karstic springs in the area, named Chenareh, Amir, Zaz, Sarabsorkheh, Papi, and Honam. The first four springs originate from the Jurassic-Cretaceous rocks of the northern part of the area. The springs of Papi and Honam originate from the Eocene formation in the south-east of 
the study area. The monthly discharge of the springs is represented in the Table 1 .

Table 1: Monthly discharge of the karstic springs of Alashtar.

\begin{tabular}{|c|c|c|c|c|c|c|c|c|c|c|c|c|c|}
\hline \multirow{2}{*}{$\begin{array}{c}\text { Name of } \\
\text { the Spring }\end{array}$} & \multicolumn{10}{|c|}{ Monthly discharge of the springs $\left(\mathbf{m}^{3} / \mathbf{s}\right)$} & Annual Average \\
\hline Oct. & Nov. & Dec. & Jan. & Feb. & Mar. & Apr. & May & Jun. & Jul. & Aug. & Sep. & Discharge (1/s) \\
\hline Chenare & 0.205 & 0.210 & 0.367 & 0.362 & 0.354 & 0.360 & 0.409 & 0.644 & 0.360 & 0.355 & 0.340 & 0.330 & 360 \\
\hline Amir & 0.638 & 0.546 & 0.477 & 0.394 & 0.456 & 0.462 & 0.576 & 0.651 & 0.791 & 0.817 & 0.673 & 0.665 & 587 \\
\hline Zaz & 0.743 & 0.355 & 0.339 & 0.319 & 0.621 & 0.530 & 4.570 & 4.450 & 0.404 & 1.817 & 1.639 & 0.730 & 1636 \\
\hline Papi & 0.107 & 0.111 & 0.920 & 0.980 & 0.114 & 0.205 & 0.132 & 0.250 & 0.214 & 0.202 & 0.174 & 0.089 & 274 \\
\hline Honam & 0.522 & 0.476 & 0.433 & 0.451 & 0.855 & 0.865 & 0.880 & 0.280 & 0.851 & 0.748 & 0.654 & 0.445 & 634 \\
\hline Sarabsorkhe & 0.040 & 0.044 & 0.038 & 0.038 & 0.047 & 0.065 & 0.070 & 0.080 & 0.082 & 0.075 & 0.077 & 0.065 & 26 \\
\hline
\end{tabular}

\section{Hydrochemistry}

Water samples from the karstic springs, groundwater aquifer, and rivers show that the water samples from the chemical analysis point of view are of bicarbonate type. Fig. 6 shows the piper diagram of the water samples. Water samples of the springs were also analysed for oxygen-18 and Deuterium. All the water samples lie on the World Meteoric Line. A comparison was made with the

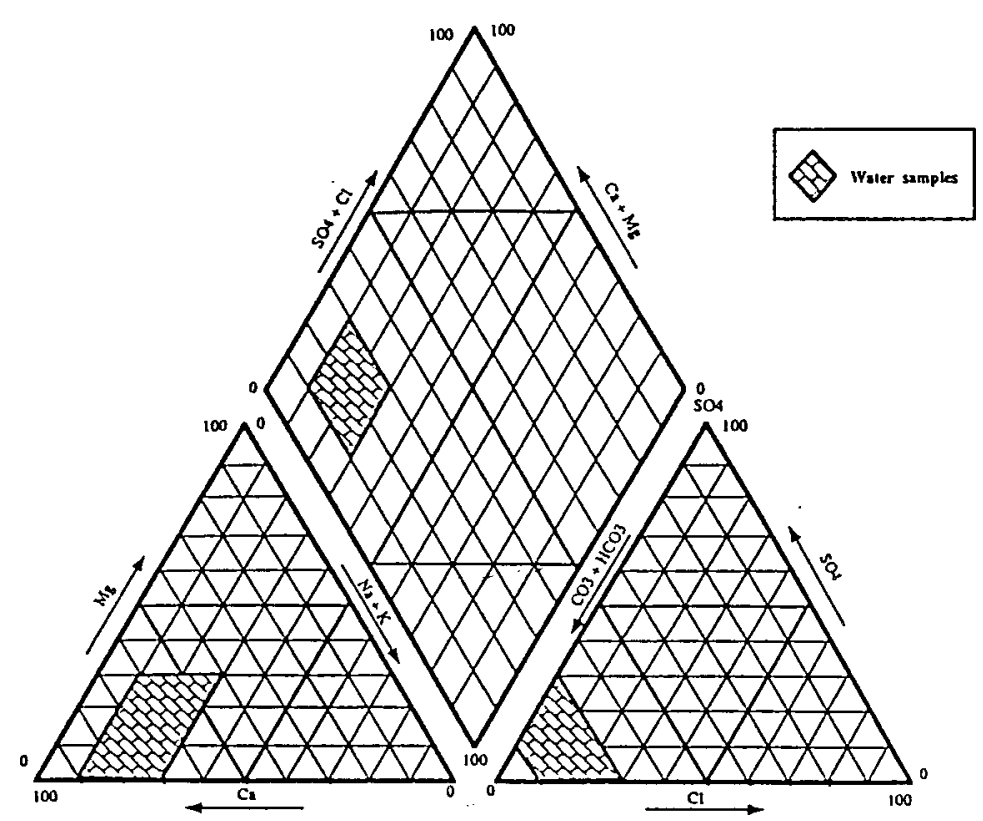

Fig. 6: The piper diagram of the water samples. 


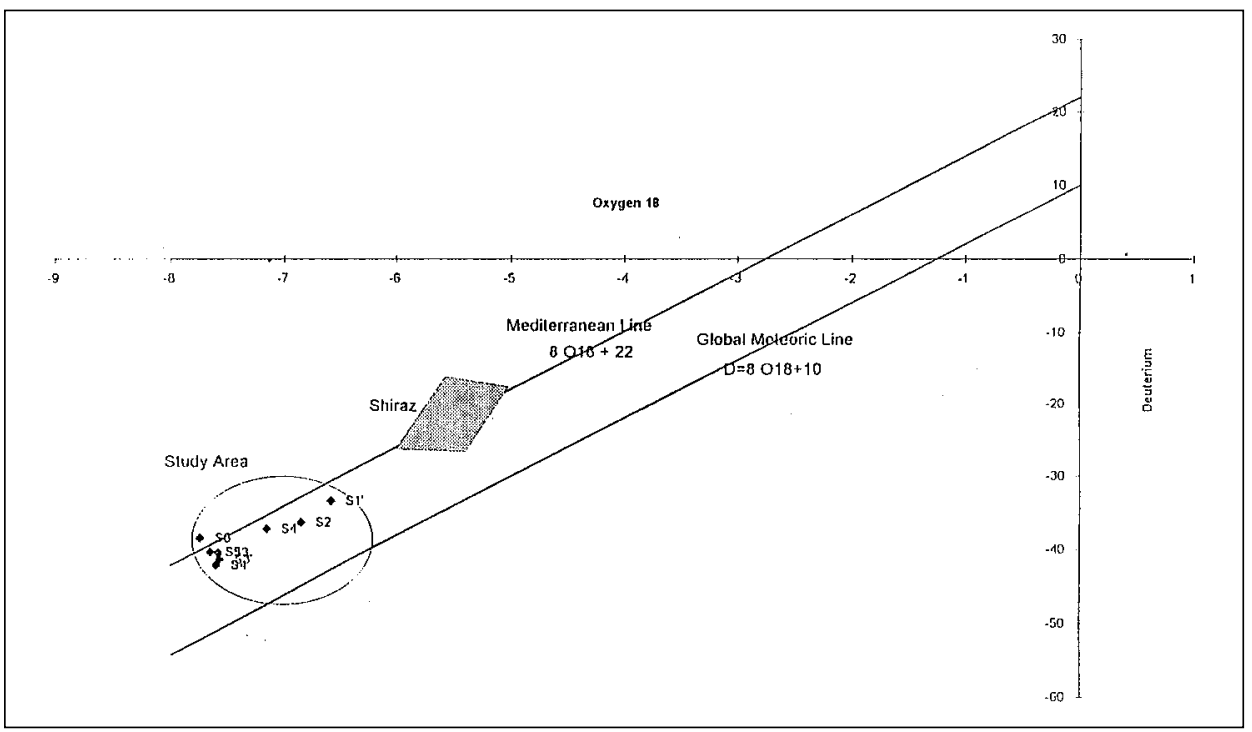

Fig. 7: Relation between oxygen-18 and Deuterium of the water samples of the study area and Shiraz (south Iran).

water samples of Shiraz (south of Iran). Fig. 7 shows the oxygen-18 and Deuterium of the water samples. The chemical analyses of the water samples is shown in the Table 2.

Table 2: Chemical analyses of the water samples of Alashtar.

\begin{tabular}{|c|c|c|c|c|c|c|c|c|c|c|c|c|c|c|}
\hline \multirow{2}{*}{$\begin{array}{c}\text { Name of } \\
\text { water } \\
\text { sample }\end{array}$} & \multicolumn{8}{|c|}{ concentration in meq/l } & \multirow{2}{*}{$\begin{array}{c}\mu \mathrm{mho} / \mathrm{cm} \\
\mathrm{EC}\end{array}$} & \multirow{2}{*}{$\begin{array}{c}\mathrm{mg} / \mathrm{l} \\
\text { TDS } \\
\end{array}$} & \multirow{2}{*}{\begin{tabular}{|c} 
Total \\
Hardnes \\
mg/l
\end{tabular}} & \multirow[b]{2}{*}{ SAR } & \multirow[b]{2}{*}{$\mathrm{Na} \%$} & \multirow[b]{2}{*}{$\mathrm{pH}$} \\
\hline & $\mathrm{Ca}^{++}$ & $\mathbf{M g}^{++}$ & $\mathrm{Na}^{+}$ & Sum & $\mathrm{HCO}_{3}{ }^{2}$. & $\mathrm{Cl}^{-}$ & $\mathrm{SO}_{4}^{2 .}$ & Sum & & & & & & \\
\hline $\begin{array}{c}\text { Kahman } \\
\text { River (R1) }\end{array}$ & 2.4 & 0.50 & 0.12 & 3.02 & 2.70 & 0.29 & 0.25 & 3.24 & 312 & 198 & 185 & 0.10 & 3.3 & 7.6 \\
\hline $\begin{array}{c}\text { Duab } \\
\text { River (R2) }\end{array}$ & 4.7 & 0.90 & 0.30 & 5.90 & 3.56 & 0.31 & 0.29 & 4.16 & 421 & 347 & 250 & 0.22 & 5.5 & 7.6 \\
\hline $\begin{array}{c}\text { Papi } \\
\text { Spring (S1) }\end{array}$ & 2.7 & 0.90 & 0.09 & 4.50 & 3.25 & 0.30 & 0.10 & 3.65 & 316 & 193 & 195 & 0.07 & 2.4 & 7.2 \\
\hline $\begin{array}{c}\text { Honam } \\
\text { Spring (S2) }\end{array}$ & 2.3 & 0.90 & 0.15 & 4.25 & 3.20 & 0.14 & 0.26 & 3.60 & 398 & 260 & 185 & 0.10 & 0.5 & 7.5 \\
\hline $\begin{array}{c}\text { Zaz } \\
\text { Spring (S3) }\end{array}$ & 2.5 & 0.60 & 0.04 & 3.14 & 2.50 & 0.25 & 0.35 & 3.10 & 293 & 204 & 160 & 0.03 & 1.2 & 7.8 \\
\hline $\begin{array}{c}\text { Amir } \\
\text { Spring (S4) }\end{array}$ & 2.6 & 0.50 & 0.11 & 3.21 & 2.60 & 0.30 & 0.38 & 3.28 & 247 & 188 & 195 & 0.09 & 3.4 & 7.7 \\
\hline $\begin{array}{c}\text { Chenare } \\
\text { Spring (S5) }\end{array}$ & 2.7 & 1.80 & 0.84 & 5.34 & 3.40 & 1.15 & 0.71 & 5.26 & 497 & 327 & 180 & 0.56 & 5.7 & 7.5 \\
\hline
\end{tabular}




\section{Karst in Khorramabad}

The carbonate rocks in Khorramabad includes the Asmari, Lower and Upper Cretaceous.

Due to the processes of karstification, solutional features such as karren and caves have been developed. The intensity of tectonic activities varies in the different parts of the rocks.

\section{Springs}

In the area under study 41 karstic springs have been recognised, out of which seven important ones have been taken into consideration. These springs are Changai, Motahari, Golestan, Gerdabsangi, Robat, Sabor and Q.

The spring of Sabor originates from the Asmari formation along the bedding plane in southern part of the area. The Robat spring also originates from the Asmari formation, but in the northern part of the area.

The Changai spring flows at the nose of the Cretaceous limestone with the development of the solutional features. The Gerdab spring flows at the foot of the Cretaceous limestone. The Motahari and the Golestan springs originate at the contact of the Lower and Upper Cretaceous limestones. The famous monument of Ghale-Falkalaflak is constructed at the Golestan spring. The spring of Q originates from the Upper Cretaceous limestone and flow at the nose of the formation in the northern part of the city. An artificial lake has been constructed around the spring. Due to the high oscillation of the springflow, sometimes the lake becomes completely dry. All the karstic springs show discharge variation during the seasons, the exception to some extend being the Sabor spring (Table 4). In the carbonate rock of the Lower Cretaceous, it can be seen that the solutional features are more developed near the Changai spring. All these springs are being used for agricultural and drinking purposes. At present the drinking water of the city is supplied from these springs. The daily drinking water discharge is 1 cubic meter per second.

Table 3: Chemical analyses of the karstic springs of Khorramabad.

\begin{tabular}{|c|c|c|c|c|c|c|c|c|c|c|c|c|c|}
\hline \multirow{2}{*}{$\begin{array}{c}\text { Name of } \\
\text { water } \\
\text { sample }\end{array}$} & \multicolumn{7}{|c|}{ concentration in meq/l } & \multirow{2}{*}{$\begin{array}{c}\mu \mathrm{mh} 0 / \mathrm{cm} \\
\mathrm{EC}\end{array}$} & \multirow[b]{2}{*}{ TDS } & \multirow[b]{2}{*}{$\mathbf{H}$} & \multirow[b]{2}{*}{ SAR } & \multirow[b]{2}{*}{$\mathrm{Na} \%$} & \multirow[b]{2}{*}{$\mathrm{pH}$} \\
\hline & $\mathrm{Ca}^{++}$ & $\mathrm{Mg}^{++}$ & $\mathrm{Na}^{+}$ & $\mathbf{K}^{+}$ & $\mathrm{HCO}_{3}{ }^{2-}$ & $\mathrm{Cl}^{-}$ & $\mathrm{SO}_{4}^{2-}$ & & & & & & \\
\hline Sabor & 4.1 & 1.59 & 0.36 & 0.06 & 5.2 & 0.4 & 0.74 & 680 & 446 & 302 & 0.21 & 5.56 & 7.36 \\
\hline Gerdab & 3.35 & 1.05 & 0.52 & 0.15 & 2.85 & 0.81 & 0.32 & 529 & 346 & 220 & 1 & I & 1 \\
\hline Golestan & 3.3 & 0.9 & 0.24 & 0.07 & 3.5 & 0.35 & 0.57 & 426 & 279 & 175 & 0.16 & 5.32 & 7.26 \\
\hline Motahari & 3.25 & 0.95 & 0.46 & 0.07 & 3.6 & 0.4 & 0.63 & 353 & 297 & 210 & 0.32 & 9.72 & 7.4 \\
\hline Robat & 3.8 & 1.2 & 1.8 & 0.2 & 4.15 & 1.9 & 0.81 & 718 & 479 & 250 & 1.14 & 25.7 & 7.32 \\
\hline Q & 3.15 & 0.8 & 0.13 & 0.05 & 3.3 & 0.25 & 0.4 & 399 & 260 & 198 & 0.09 & 3.15 & 7.71 \\
\hline Changai & 3.00 & 1.7 & 0.36 & 0.09 & 3.95 & 0.4 & 0.68 & 531 & 348 & 235 & 0.23 & 6.99 & 1 \\
\hline
\end{tabular}




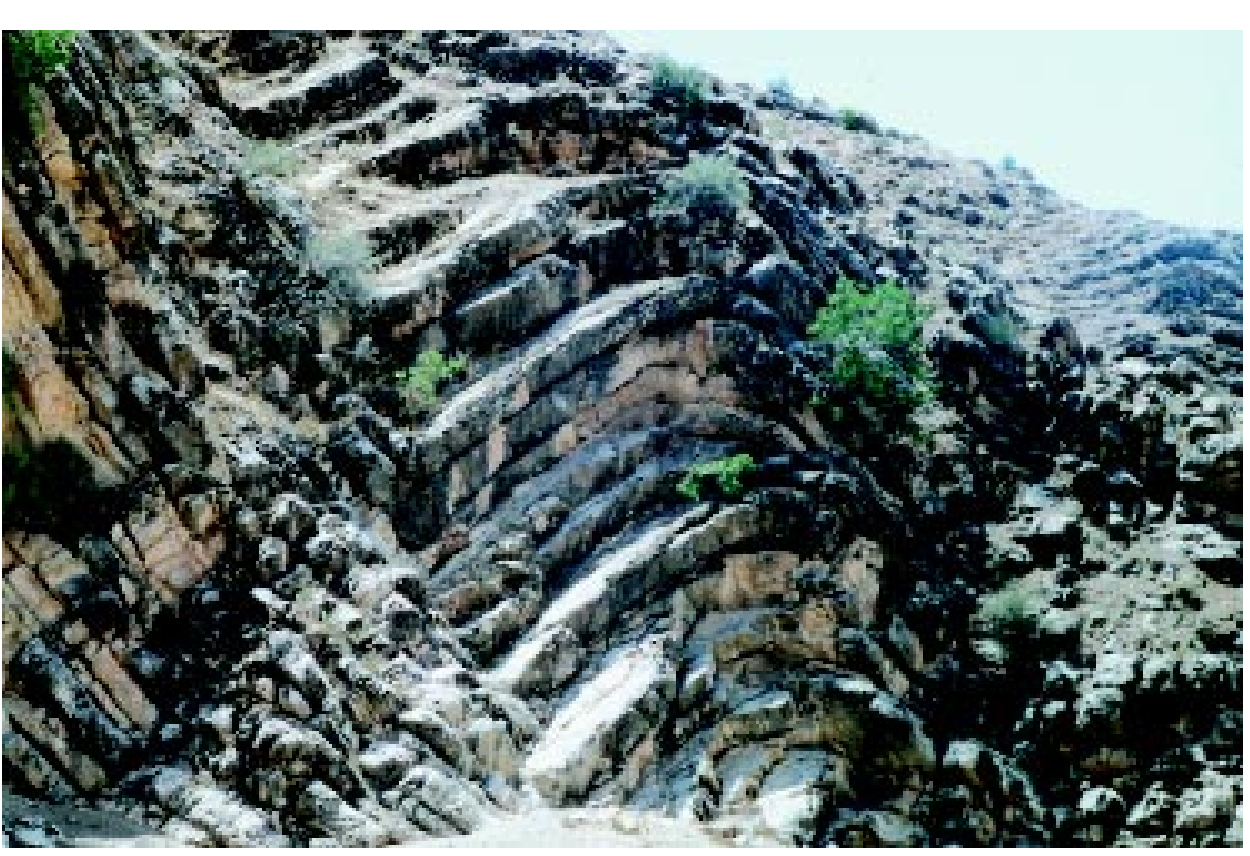

Fig. 3: Folds in Islam formation (Photo Ahmadipour).

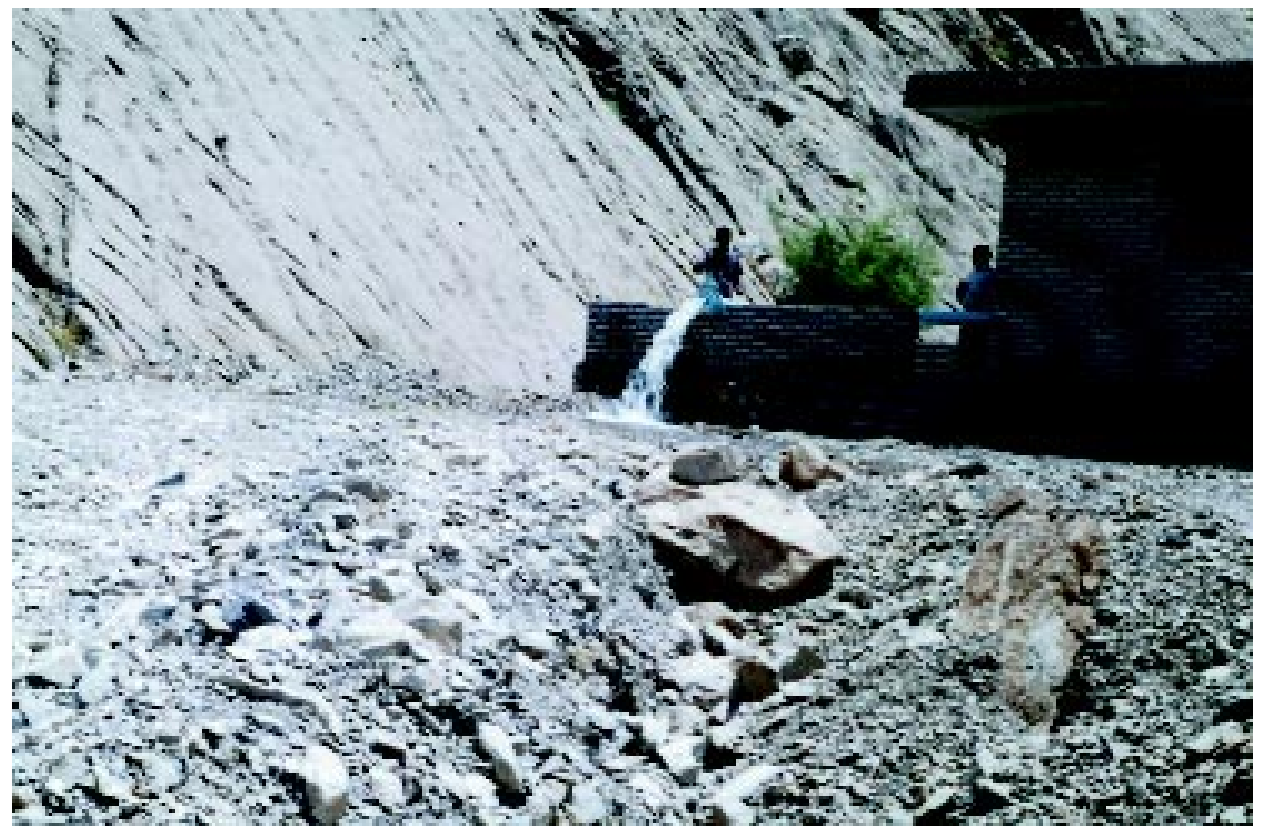

Fig. 5: Location of the well no. 3 (Photo Ahmadipour). 


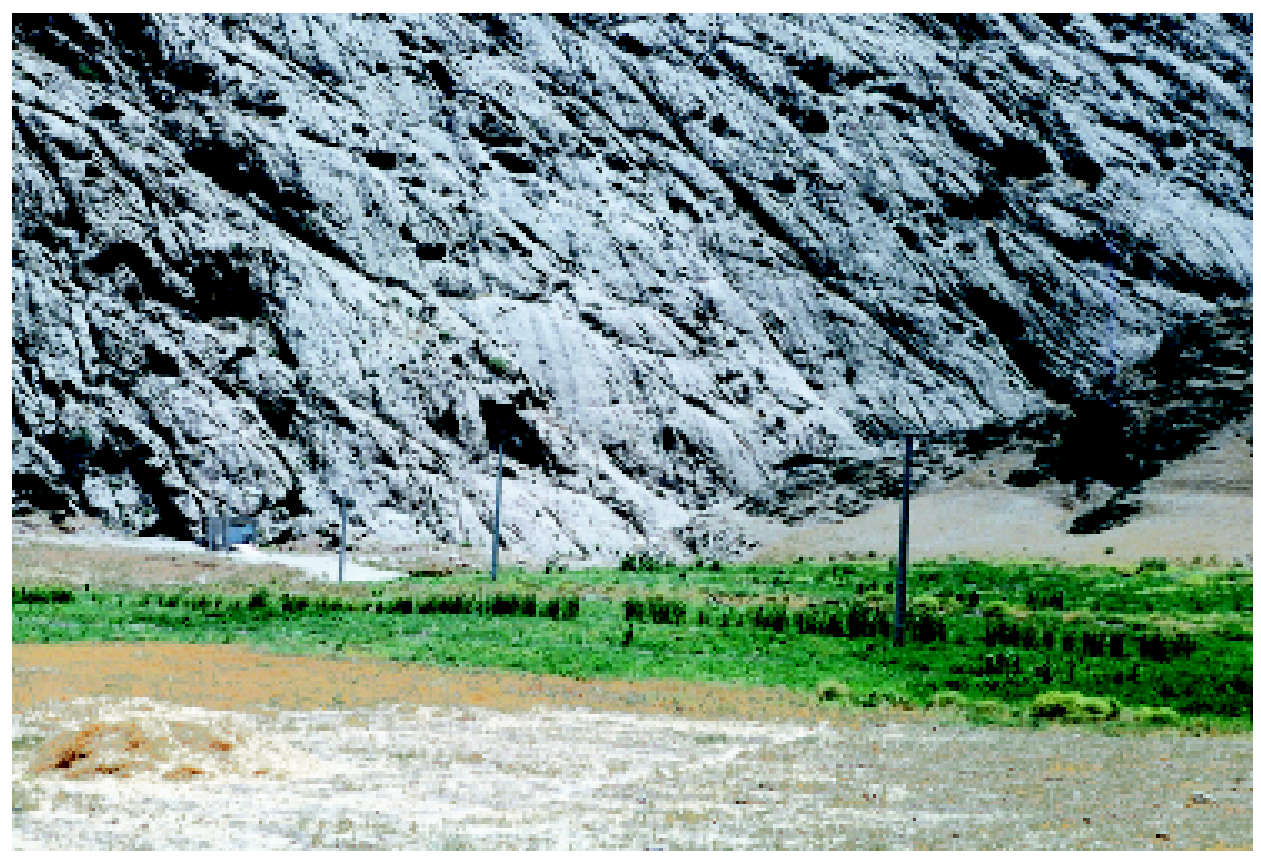

Fig. 8 and 9: Karst landscape in Iran (Photo Ahmadipour).

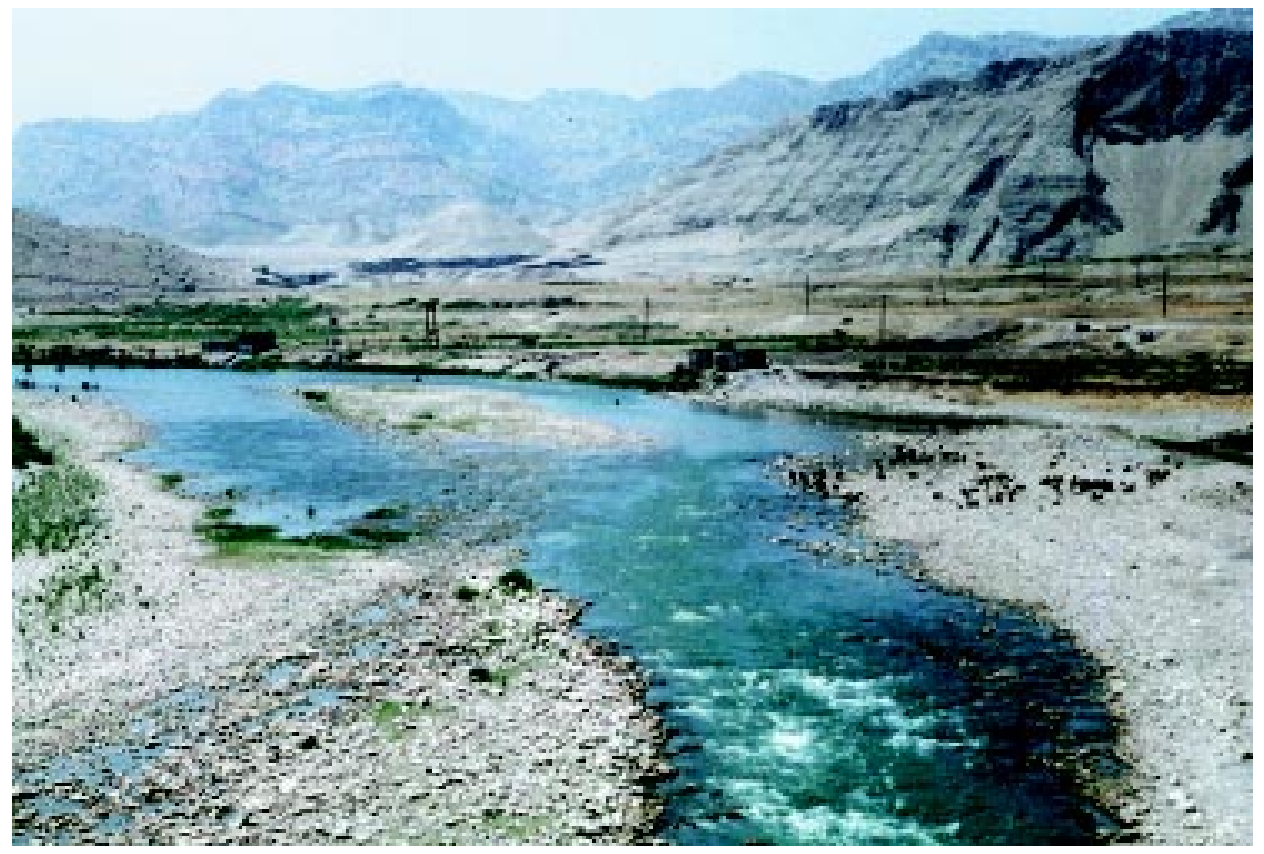




\section{Chemical analyses}

Analyses of the water samples are shown in the Table 5. In this area such as Alashtar the type of the water is of bicarbonate, but the concentrations of the ions $\mathrm{HCO}_{3}{ }^{2-}, \mathrm{Ca}^{2+}$, and $\mathrm{Mg}^{2+}$ and the parameters such as electrical conductivity (E.C.) and total dissolved solutes (T.D.S.) are higher than in the water samples from Alashtar. Table 5 shows the chemical analyses of the springs. Since many houses have been constructed around the springs, there is possibility of pollution. The concentration of nitrate in the Q spring is reported to be more than $35 \mathrm{mg}$ per litre.

Table 4: Monthly discharge of the karstic springs of Khorramabad.

\begin{tabular}{|c|c|c|c|c|c|c|c|c|c|c|c|c|}
\hline \multirow{2}{*}{$\begin{array}{l}\text { Name of } \\
\text { the Spring }\end{array}$} & \multicolumn{12}{|c|}{ Monthly discharge of the springs $(\mathrm{l} / \mathrm{s})$} \\
\hline & Oct. & Nov. & Dec. & Jan. & Feb. & Mar. & Apr. & May & Jun. & Jul. & Aug. & Sep. \\
\hline Sabor & 49 & 45 & 25 & 18 & 15 & 14 & 48 & 43 & 61 & 33 & 33 & 24 \\
\hline Gerdab & 102 & 39 & 19 & 66 & 600 & 359 & 614 & 43 & 314 & 166 & 54 & 6 \\
\hline Golestan & 630 & 680 & 830 & 600 & 1410 & 1220 & 1375 & 1098 & 765 & 555 & 546 & 723 \\
\hline Motahari & 911 & 590 & 1225 & 934 & 1466 & 1411 & 1761 & 1857 & 1508 & 1100 & 842 & 897 \\
\hline Robat & 1024 & 613 & 116 & 105 & 216 & 1883 & 2140 & 2308 & 1263 & 988 & 772 & 884 \\
\hline Q & 299 & 50 & 196 & 296 & 2422 & 1183 & 1443 & 1634 & 1098 & 1036 & 425 & 96 \\
\hline Changai & 858 & 443 & 374 & 363 & 601 & 651 & 663 & 536 & 555 & 936 & 926 & 594 \\
\hline
\end{tabular}

Table 5: Chemical analyses of water samples of Sultan Anticline.

\begin{tabular}{|c|c|c|c|c|c|c|c|c|c|c|c|c|c|}
\hline \multirow{2}{*}{$\begin{array}{c}\text { Name of } \\
\text { water } \\
\text { sample } \\
\end{array}$} & \multicolumn{7}{|c|}{ meq/l } & \multirow{2}{*}{$\begin{array}{l}\mathrm{NO}_{3} \\
\mathrm{mg} / \mathrm{l}\end{array}$} & \multirow{2}{*}{$\begin{array}{c}\mu \mathrm{mho} / \mathrm{cm} \\
\mathrm{EC} \\
\end{array}$} & \multirow[b]{2}{*}{ TDS } & \multirow{2}{*}{$\begin{array}{c}\text { Total } \\
\text { Hardnes } \\
\end{array}$} & \multirow[b]{2}{*}{$\mathrm{pH}$} & \multirow[b]{2}{*}{$\mathbf{T}\left({ }^{\circ} \mathrm{C}\right)$} \\
\hline & $\mathrm{Ca}^{++}$ & $\mathrm{Mg}^{++}$ & $\mathrm{Na}^{+}$ & $\mathbf{K}^{+}$ & $\mathrm{HCO}_{3}{ }^{2-}$ & $\mathrm{Cl}^{-}$ & $\mathrm{SO}_{4}^{2-}$ & & & & & & \\
\hline Well (1) & 1.34 & 2.15 & 0.81 & 0.05 & 3.21 & 0.29 & 1.89 & 18.1 & 576 & 296 & 174.5 & 7.6 & 21 \\
\hline Well (2) & 1.39 & 2.30 & 1.16 & 0.05 & 2.62 & 0.23 & 2.96 & 23.4 & 660 & 356 & 184.5 & 7.5 & 22 \\
\hline Well (3) & 1.44 & 2.58 & 1.31 & 0.06 & 2.79 & 0.22 & 2.99 & 29.4 & 716 & 434 & 199.5 & 7.8 & 22 \\
\hline $\begin{array}{l}\text { Sultan } \\
\text { spring }\end{array}$ & 1.09 & 1.56 & 0.44 & 0.06 & 2.26 & 0.26 & 0.15 & - & 66 & 240 & 132.5 & 8.1 & - \\
\hline $\begin{array}{l}\text { Zale-Morian } \\
\text { spring }\end{array}$ & 3.2 & 4.87 & 5.6 & 0.05 & 3.82 & 5.2 & 5.4 & 4.93 & 910 & 450 & 410 & - & - \\
\hline
\end{tabular}




\section{REFERENCES}

Ahmadipour, M. R., 1989: Study of the carbonate rocks of Lorestan.- Publ. Higher Education Complex of Lorestan.

Ahmadipour, M. R. [1999]: Hydrogeological Investigations of Alashtar Basin (West of Iran).Proceedings $2^{\text {nd }}$ Intern. Symposium on Karst water Resources I.R. Iran - Tehran - Kermanshah July 1998, 174 - 196, [Tehran].

Colman \& Sadd, S. P. (1978): Fold Development in Zagros Simply Folded Belt, AAPG. Bull. Vol. 62.

Price, N. J. \& Cosgrove, J. W. (1990): Analysis of Geological Structures, Cambridge University Press.

Raeisi, E. \& N. Kowsar, 1997: Development of Sha[h]pour Cave, Southern Iran.- Cave and Karst Science, Vol. 24, No. 1, 27-34, Nottingham

Ramsay, J. G. \& Huber, M. I. (1987): The Techniques of Modern Structural Geology, Vol. 2.: Folds and Fractures, Academic press, London.

Rowland, S. M. (1986): Structural Analysis and Synthesis.

\section{KRAS V IRANU - PRIMERI IZ LORESTANA}

\section{Povzetek}

Kraški svet predstavlja 13 \% ozemlja Irana. Ker je Iran v osrednjem alpsko-himalajskem pasu in med evrazijsko ploščo na severu ter gondwansko (afriško-arabsko) na jugu, predstavljajo sekundarni prelomi ugodne razmere za razvoj krasa. Karbonatne kamnine so eocenske, oligomiocenske, miocenske, jurske in kredne starosti. Večina jih je razvitih v bazenih Mazindarana in Zagrosa. Zaradi prevladujočih tektonskih aktivnosti so kamnine zagroške cone bolj zakrasele. Okoli $56 \%$ vseh izvirov in velikih rek priteka prav iz te cone. Zagroško cono v Lorestanu sestavljajo serije vzporednih antiklinal, v katerih so, zaradi tektonskih premikov, kamnine nagubane in razpokane. Nagubanost in prepokanost je osnova bogatih vodonosnikov. Pretok nekaterih kraških izvirov dosega $3 \mathrm{~m}^{3}$ vode v sekundi. Dvoje pomembnih porečij, Dez in Karkhah, dobivata vodo iz karbonatnih kamnin v Lorestanu. Njun letni pretok znaša 12 miljard kubičnih metrov.

V karbonatnih kamninah Lorestana so razvite vse kraške oblike, kot so škraplje, vrtače in jame. Večina izvirov prihaja na površje vzdolž tektonskih linij ali na sečiščih teh linij. Kemijske analize potrjujejo, da so to bikarbonatne vode. Čeprav so vse vode bikarbonatne, je opaziti postopno naraščanje koncentracije ionov od severnega proti južnemu delu Lorestana. V južnem delu Lorestana je velik obseg površja na karbonatnih kamninah in tako površinske kot podzemeljske kraške oblike so najbolje razvite v skupini Bangeston. Da bi preskrbeli s pitno vodo okoli 20000 prebivalcev mesta Doghtar, ki leži na kraškem polju, so v vznožju antiklinale Sultan izvrtali tri črpalne vodnjake. Danes črpajo iz njih okoli 120 litrov vode v sekundi. Tudi prestolnica Lorestana, Khorramabad, se oskrbuje z vodo iz kraških izvirov.

Podzemeljske korozijske oblike so najpomembnejše poti za prevajanje in skladiščenje vodnih zalog, vendar so zaradi visoke prevodnosti močno občutljive na onesnaženje. Visoka koncentracija nitratov v nekaterih kraških vodah province Lorestan je že eden od pokazateljev onesnaženja. 